\title{
A review of studies of childhood cancer and natural background radiation
}

DOI:

10.1080/09553002.2020.1867926

\section{Document Version}

Accepted author manuscript

Link to publication record in Manchester Research Explorer

\section{Citation for published version (APA):}

Kendall, G. M., Little, M. P., \& Wakeford, R. (2021). A review of studies of childhood cancer and natural background radiation. International Journal of Radiation Biology, 97(6), 769-781.

https://doi.org/10.1080/09553002.2020.1867926

\section{Published in:}

International Journal of Radiation Biology

\section{Citing this paper}

Please note that where the full-text provided on Manchester Research Explorer is the Author Accepted Manuscript or Proof version this may differ from the final Published version. If citing, it is advised that you check and use the publisher's definitive version.

\section{General rights}

Copyright and moral rights for the publications made accessible in the Research Explorer are retained by the authors and/or other copyright owners and it is a condition of accessing publications that users recognise and abide by the legal requirements associated with these rights.

\section{Takedown policy}

If you believe that this document breaches copyright please refer to the University of Manchester's Takedown Procedures [http://man.ac.uk/04Y6Bo] or contact uml.scholarlycommunications@manchester.ac.uk providing relevant details, so we can investigate your claim.

\section{OPEN ACCESS}




\section{A review of studies of childhood cancer and natural background radiation}

Gerald M Kendall ${ }^{\mathrm{a}, 1}$, Mark P Little ${ }^{\mathrm{b}}$ and Richard Wakeford ${ }^{\mathrm{c}}$

${ }^{a}$ Cancer Epidemiology Unit, NDPH, University of Oxford, Richard Doll Building, Old Road Campus, Headington, Oxford, OX3 7LF, UK.

bRadiation Epidemiology Branch, National Cancer Institute, Bethesda, MD 20892-9778, USA ${ }^{\mathrm{c}}$ Centre for Occupational and Environmental Health, Faculty of Biology, Medicine and Health, The University of Manchester, Ellen Wilkinson Building, Oxford Road, Manchester, M13 9PL, UK

${ }^{1}$ All communications to Dr G M Kendall, Cancer Epidemiology Unit, Nuffield Department of Population Health, University of Oxford, Richard Doll Building, Old Road Campus, Headington, Oxford, OX3 7LF, UK.

Keywords: Background radiation, Cancer, Epidemiology 


\begin{abstract}
Purpose: The projected existence and magnitude of carcinogenic effects of ionising radiation at low doses and low dose rates is perhaps the most important issue in radiation protection today. Studies of childhood cancer and natural background radiation have the potential to throw direct light on this question, into a dose range below a few tens of mSv. This paper describes the studies that have been undertaken and their context, discusses some problems that arise and summarizes the present position.

Conclusions: Many such studies have been undertaken, but most were too small to have a realistic chance of detecting the small effects expected from such low doses, based on risk projections from higher exposures. Case-control or cohort studies are to be preferred methodologically to ecological studies, but can be prone to problems of registration/participation bias. Interview-based studies of the requisite size would be prohibitively expensive and would undoubtedly also run into problems of participation bias. Register-based studies can be very large and are free of participation bias. However, they need to estimate the radiation exposure of study subjects using models rather than individual measurements in the homes of those concerned. At present no firm conclusions can be drawn from the studies that have been published to date. Further data and perhaps pooled studies offer a way forward.
\end{abstract}




\section{Introduction}

Radiation protection was first developed to manage the risks of medical exposures. However, after the Second World War, military and peaceful uses of nuclear fission came to dominate the subject, as they arguably still do. Interest in natural background radiation was, perhaps surprisingly, slow to develop given that ubiquitous naturally occurring radiation predated both medical and military/industrial fission applications and that the deleterious effect of natural sources of radiation, in the form of "Schneeberger Lungenkrankheit" (Schneeberger Lung Disease - lung cancer) had been known for centuries albeit not under that name. However, the recognition that natural background radiation, specifically emissions from radon decay products, was responsible was slow to come (International Commission on Radiological Protection 1993).

In the years after the Second World War, there was both professional and public concern about possible effects of environmental radioactivity, largely driven by anxiety about fallout from atmospheric testing of nuclear weapons (Commoner 1958) (Arnold 2001). The Castle Bravo test in 1954 in the Marshall Islands attracted particular attention (Arnold 2001; Simon 1997; Simon et al. 2010). The yield, 15 megatons, was two or three times that expected and the fallout was much more extensive. Both the crew of the "Lucky Dragon", a Japanese fishing vessel, and the inhabitants of Rongelap and Utirik atolls suffered acute radiation effects. But at least as important as concerns about the acute effects of local fallout were anxieties about global fallout and about its genetic and somatic consequences.

The increased awareness of the possible dangers from radiation led to an upsurge of interest in natural background radiation. Like global fallout, this affected the entire population of the world and might provide a yardstick against which man-made sources of radiation could be judged. However, there was little quantitative knowledge about population exposures from

natural sources. In this context, the United Nations Scientific Committee on the Effects of Atomic Radiation (UNSCEAR) was set up in 1955 in order to "define precisely the present exposure of the population of the world to ionizing radiation." UNSCEAR's success can be 
seen in the expansion of the sections on naturally occurring radiation sources in successive UNSCEAR Reports. In the 1958 Report (UNSCEAR 1958) there were 40 paragraphs (with just one on radon) and 50 references. By the 1977 Report (UNSCEAR 1977) it had grown to 213 paragraphs and 378 references and in the 1988 Report (UNSCEAR 1988) there were 276 paragraphs and 492 references, radon and its short-lived decay products having a substantial section to themselves. Moreover, there was a change in emphasis. In the 1950s and 1960s "background radiation" meant gamma- and cosmic rays. By the 1980s, the emphasis was firmly on radon see, for example, Sinnaeve et al 1984 (Sinnaeve et al. 1984). Many countries undertook surveys of natural background radiation, initially of gamma-rays (with or without cosmic rays) and later of radon concentrations (UNSCEAR 1977, 1988). This activity was encouraged by the development of track-etch detectors for radon and passive detectors such as TLDs for low LET radiation which allowed radiation surveys to be carried out by post.

An early study of the effects of natural background radiation was by Court-Brown et al. (Court Brown et al. 1960) who investigated the question of whether variations in natural background gamma radiation might explain regional variations in leukemia mortality (at all ages) in Scotland. Using accepted risk factors, they concluded that background radiation could not be responsible and that other factors must be at work. Other studies followed, most of "ecological" design in which levels of disease in different geographical areas were compared with mean radiation levels in these areas. Some of these studies investigated variations between geologies expected to produce higher and lower gamma-ray dose rates (e.g., Pincet 1975 (Pincet and Massé 1975)) or variations with altitude, which affects cosmic ray doses (e.g., Mason 1974 (Mason and Miller 1974)). But other studies investigated trends with mean dose rates (e.g., Jacobson 1976 (Jacobson et al. 1976). Most of these studies considered cancers at all ages. One exception was the study of children by Sakka 1979 (Sakka 1979). Studies of children might well have a better chance of detecting the effects of low-level radiation, partly because children are generally more radio-sensitive and partly because background rates of cancer, and their variations, rise sharply with age, thereby increasing the degree of extra-Poisson variation 
and statistical "noise", which might hide any radiation signal This increase in levels of cancer with age is, at least in part, due to the increasing influences of environmental carcinogens such as tobacco smoke.

Because of the known association between lung cancer and radon exposure in underground hard-rock miners many investigators were attracted to studies investigating a possible link between lung cancers and domestic exposure to radon. However, Stidley and Samet (Stidley and Samet 1993) reviewed 15 such ecological studies published between 1981 and 1991, and concluded that inherent methodologic limitations substantially bias ecological estimates of risk and that such studies threw little light on the question of associations between lung cancer and radon exposure in the general population. One of the main problems was that smoking is a dominant cause of lung cancer and that ecological studies could not take proper account of smoking. There are well known potential biases in ecological studies quite generally (Greenland and Robins 1994) (Piantadosi et al. 1988) and in particular with the ecological studies that have been conducted of lung cancer and radon exposure (Lubin 2002). In fact, it would take many years for carefully conducted case-control studies which included detailed information on smoking to demonstrate a link between lung cancer and domestic exposure to radon (Darby et al. 2005; Krewski et al. 2006; Lubin et al. 2004)

A particularly vivid illustration of the importance of properly accounting for smoking, and in particular the dangers of ecological bias in studies of lung cancer, came from work by Cohen. Cohen conducted an ecological study reporting a strong negative association between average radon levels and lung cancer mortality rates in US Counties (Cohen 1995, 2000). However, Puskin (Puskin 2003) found a similar inverse trend of cancer mortality with radon level in US Counties for other smoking-related cancers, but not for cancers unrelated to smoking. Cohen had attempted to adjust for smoking prevalence at the county level through the use of cigarette sales data; however, the means by which such adjustments were made had failed to account for unmeasured intra-area confounding by smoking and non-linearities in the effects of radon exposure and its interaction with smoking. The problem of cigarette smoking 
illustrates why studies of cancer in adulthood are likely to be much more difficult than those of childhood cancer. Unlike in childhood, there are many potential exposures, constitutional and medical factors and lifestyle factors that may affect cancer rates in adulthood. Because these factors are likely to be much more important than background radiation in their effect on cancer risk, there is a much more serious risk of bias due to unmeasured confounding factors than for childhood exposure (Gilbert et al. 2020).

In 1956 Alice Stewart and co-workers published the first results (Stewart et al. 1956) from a large case-control study, the Oxford Survey of Childhood Cancers (OSCC), which suggested that the low fetal doses involved in obstetric radiography lead to an increased risk of cancer in children. Such a revolutionary hypothesis was not accepted at once, bias in the recall of exposures by mothers being an obvious potential problem. But over the next twenty years or so the association came to be generally accepted as genuine and a causal interpretation regarded as likely (UNSCEAR 1977). This early paper (which did not itself consider natural background radiation) was very influential and stimulated interest in the possibility of childhood cancer being induced by other forms of radiation including natural background radiation. Indeed, it was Stewart and her colleagues who were some of the first to conduct a study to look for such an association (Kneale and Stewart 1987; Knox et al. 1988). However, it should be noted that the analysis in this work used non-standard methods, and the results are therefore to some extent unreliable (Muirhead and Kneale 1989; Muirhead et al. 1992).

A number of epidemiological studies of childhood cancer and natural sources of radiation have been published in the last three decades and these are the subject of the present paper. By "natural sources of radiation" we mean natural gamma- and cosmic-rays and radon with its short-lived decay products. We do not consider other radionuclides within the body; these internal emitters (e.g., Ra-226, Po-210) make a significant contribution to the dose to the population (UNSCEAR 1988), but difficulties in individual dose assessment make epidemiological studies of their effects almost impossible. Most people spend the majority of their time at home and will incur most of their natural background dose there, and domestic 
exposure is likely to be particularly important for children under the age of 5 years (i.e., before they start full-time school). There will, of course be contributions from exposures elsewhere, but we shall concentrate on exposures in the home.

A number of reviews of the effects, other than lung cancer, of radon exposure should be mentioned: Laurier et al (Laurier et al. 2001) considered radon and leukemia at all ages, Raaschou-Nielsen (Raaschou-Nielsen 2008) radon and childhood leukemia, as did Tong et al (Tong et al. 2012). In addition, Mazzei-Abba et al (Mazzei-Abba et al. 2020) reviewed national record-based studies of natural background radiation (including radon) and childhood cancer.

\section{The Studies}

Table 1 summarizes 38 studies of childhood cancer and natural background radiation. Natural background radiation here encompasses inhaled radon with its decay products and/or terrestrial gamma rays, with or without cosmic rays. We do not consider ingested radon. In some instances, the gamma contribution may include a small contribution from artificial sources (e.g., Chernobyl fallout). In most epidemiological studies analyses are in terms of estimates of indoor gamma ray doses, but in some use outdoor doses (or both). Usually, "children" are taken to be those aged up to the fifteenth birthday, but there is some variation between the studies listed in the table.

Most of the studies (26 out of 38) considered only leukemia or subtypes thereof and almost all included an analysis of leukemia. Lymphomas and CNS tumors are the next most studied childhood cancers.

In terms of study design, there are roughly equal numbers of ecological (19) and casecontrol (16) studies, with three cohort studies. Most (22 out of 38) of the studies investigated radon only, 10 studies investigated both radon and gamma rays and the remaining six, gamma rays alone.

Many early studies focus on radon and are of ecological design. As suggested above, this was possibly a consequence of the availability of radon distribution maps and of the interest 
in radon as a lung carcinogen. The difficulties in conducting conventional interview-based case-control studies of natural sources of radiation without the use of passive dosemeters, as used in the radiation surveys, are illustrated in the early study by Stjernfeld (Stjernfeldt et al. 1987) in which active measurements had to be made in the homes of all study participants. This made any large-scale study quite impractical.

The trend towards studies of gamma radiation as well as, or instead of, radon was probably driven by the realization that the former almost certainly delivered higher doses to the tissues in which the important childhood tumors developed (specifically acute lymphoblastic leukemia, the dominant malignancy of childhood), lung cancer being essentially unknown in children (Simmonds et al. 1995). However, as discussed below, there are significant uncertainties in estimates of doses from short-lived radon decay products.

Another important factor in the development of these studies was a quantitative understanding of the size of study that was required for statistically significant results to be probable if a real effect existed. It is clear that many early studies were undertaken with the datasets that were available with no prior assessment of the likelihood of a significant result, or perhaps with the thought that the association being investigated might be exceptionally strong. However, formal power calculations showed that most if not all of the early studies were underpowered, often greatly so (Little et al. 2010). As shown by Land (Land 1980) if a low power study produces a statistically significant result it is almost always bound to be upwardly biased. There is also an obvious danger of reporting bias with such small studies, i.e., that studies reporting positive associations are more likely than negative ones to be written up, submitted, accepted for publication and subsequently cited. For example, amongst the studies published in the last decade it is difficult to believe that Long et al (Long et al. 2010) would have been published had it not reported a significantly positive association, no matter how well it may have been conducted; given the size of the study (56 cases and 112 controls) the play of chance may well account for the findings. 
Largely in response to this perspective a number of very large national studies have been conducted over the last decade or so. The first of these was set in Denmark and was conducted by Raaschou-Nielsen et al (Raaschou-Nielsen et al. 2008). These national studies were reviewed by Mazzei-Abba et al (Mazzei-Abba et al. 2020). Since that review, a further study has appeared, of CNS tumors in France, conducted by Berlivet et al (Berlivet et al. 2020). These register-based (sometimes referred to as "record-based") studies have substantial advantages over traditional interview-based studies. In particular, realistically sized interviewbased studies can hardly be large enough to throw light on the question of low-dose radiation risks. Almost equally important, since they are not dependent on individual consent, registerbased studies are free of the potential participation bias that can poison interview-based studies. Such participation bias is thought likely to account for some of the peculiar results - such as childhood cancer risk being inversely associated with radon exposure - in the UK Childhood Cancer Study (UKCCS) one of the largest interview-based studies (UK Childhood Cancer Study Investigators 2002b).

Despite their advantages, register-based studies also have obvious and intrinsic disadvantages. The lack of contact with study subjects precludes the collection of information from the individuals concerned. Thus, information on socioeconomic status and other possibly relevant lifestyle risk factors and exposures must be obtained in other ways, very likely based on location rather than on individual characteristics. However in the context of most childhood cancers, in particular leukemia (Linet et al. 2018), lymphoma (Cerhan et al. 2018; Hjalgrim et al. 2018) and brain cancer (Amirian et al. 2018), which have few modifying factors likely to be of importance in a general population, this is perhaps not a large concern. More importantly, it is not possible to make radiation measurements in the homes of study participants, and information on exposures must come from modelling, which will usually be based on radiation surveys.

\section{Discussion}


The effect of low doses of ionizing radiation is perhaps the most important question in radiation protection. Studies of childhood cancer and natural background radiation have the potential to offer significant evidence on this subject. Particular strengths are that they address risks in the ranges of both dose and of dose-rate that are of most interest. We now discuss some of the issues that arise with such studies, particularly the register-based studies which offer the possibility of large sample sizes, while avoiding the risk of participation bias.

\section{Estimates of radiation exposure}

Perhaps the major disadvantage of register-based studies is that the absence of contact with study participants precludes any chance of making measurements in the homes (and any previous homes) of those involved. Instead, radiation exposures must be estimated using models. Methods that have been used are summarized in the Appendix. There is little uniformity of approach, different groups making use of the data available to them. It must be recognized that estimating radon and gamma/cosmic ray exposures is difficult, particularly indoor exposures where the majority of the dose is likely to be incurred. In the case of radon, mechanisms of ingress of soil gas are likely to be very important and these notoriously vary from one building to another. For gamma/cosmic rays, the data that would be most helpful information on the shielding provided by the building materials and their radionuclide content - is essentially never available, although the residential Danish study (Raaschou-Nielsen et al. 2008) did have access to detailed individual data (via a register of individual address locations) on building material and soil type, which was used in a regression model to determine radon exposure (Andersen et al. 2007). Nikkilä et al (Nikkilä et al. 2016) were able to make use of specific information on building type. For both radon and gamma-rays all that modelling can aspire to is an estimation of mean expected values in the dwelling in question, on which substantial random variation will be superimposed.

Clearly, greater uniformity in methods of estimating indoor doses is highly desirable, both to simplify the comparison of results from different epidemiological studies and, still more, pooling studies (Daniels et al. 2020; Till et al. 2017). A fundamental requirement is that, as far 
as possible, the relevant individual organ doses and their uncertainties be estimated, in particular that active bone marrow doses be estimated for leukaemia. There is, as yet, little consensus on how this should be achieved and how these doses should best be estimated. An important point is that a model for predicting indoor radiation levels, no matter how good, is of no practical use for epidemiology if it uses data which are not available for the homes of study subjects. Thus, a radiation survey might ask householders for details of house construction. Unless the same data are available for the homes of study subjects they are valueless. Work on various methods applied to measurement data from Great Britain, described in the Appendix, may be helpful in the case of gamma-rays. Nevertheless, the possibility of national differences must be borne in mind and practical constraints are likely to be dominant. Like politics, estimating such doses is the art of the possible. A better understanding of the strengths and weaknesses of different methods for modelling indoor radiation doses is needed.

\section{Residential mobility and timing of exposure assessment}

An important question is whether radiation exposure estimates are needed for all buildings in which study subjects have lived or whether data for just the birth or diagnosis address will suffice. We suggest that while the gold standard must be to have a full residential history, a detailed examination of the factors involved suggests that, in practice, at least in several countries (Nikkilä et al. 2018), measurements at a single address, preferably that at birth, are a reasonable choice. For example, up to age 5 years (by which time the majority of childhood leukemia cases will have occurred) over $80 \%$ of children with cancer had moved less than $7 \mathrm{~km}$ from their birth address (Kendall et al. 2015). A fuller discussion is given by Mazzei-Abba et al (Mazzei-Abba et al. 2020) and by Kendall et al (Kendall et al. 2015).

\section{Confounding}

Epidemiological studies investigating the very small effects expected from natural background radiation must be very large in order to have a realistic chance of a statistically significant finding (Little et al. 2010). In such studies, confounding must always be considered as a possible complication. By confounding is meant the possibility that an association between 
agent $\mathrm{X}$ and endpoint $\mathrm{Y}$ is due not solely to a direct causal link between $\mathrm{X}$ and $\mathrm{Y}$, but is also modified by a factor $\mathrm{Z}$ (the confounding factor), a potent cause of the endpoint $\mathrm{Y}$, whose exposures are correlated with X. Thus, in the studies of Cohen described above, the (inverse) association between radon and lung cancer was in fact very likely due to intra-area correlations between radon levels and smoking combined with non-linearities introduced by interactions of radon with smoking.

It must be remembered that a confounding factor must have a sufficiently strong influence to account for an observed association. Indeed, if confounding is to be entirely responsible for an observation, the confounding factor must be at least as strongly associated with the endpoint as the agent under study (Cornfield et al. 1959). In a recent review of epidemiological studies of low-dose ionizing radiation it was shown that neither smoking nor asbestos, confounding factors that might plausibly be invoked, were, in fact, sufficiently powerful carcinogens to account for observed radiation effects on rates of all cancers excluding leukemias (SchubauerBerigan et al. 2020) (and see also Lubin et al (Lubin et al. 2018). Moreover, exposures to the confounding factor must be correlated with those to the agent under study. This is an essential condition that is sometimes overlooked.

Smoking is far and away the dominant cause of lung cancer and should always be considered as a potential confounding factor in studies of lung cancer. There are no such known dominant causes of childhood leukemia, radiation being perhaps the best-established cause (Linet et al. 2018). Nor are there known dominant causes of childhood tumors of the brain and CNS, the next most common group of childhood malignancies (Amirian et al. 2018).

There has been increasing interest in recent decades in the possibility that infective mechanisms are important in the etiology of childhood cancers, particularly leukemia. Two main hypotheses concerning infective mechanisms in the etiology of childhood leukemia have been advanced: Greaves’ Delayed Infection Hypothesis (Greaves 2018; Greaves 1988) and Kinlen's Population Mixing Hypothesis (Kinlen 1988). Both invoke an unusual pattern of infection. In the case of the Greaves' hypothesis, delayed exposure to infections early in life 
predisposing the immune system to aberrant responses following subsequent exposures; in the case of the Kinlen hypothesis, a population influx into isolated areas causing "mini-epidemics" of an infection which, in rare cases, leads to childhood leukemia. It is highly implausible that infections correlate with natural radiation levels in a simple causal way, but the possibility of some indirect link must be considered.

There have been several reports linking socioeconomic status (SES) to childhood leukemia, with higher disease rates in the more affluent (Kroll et al. 2011) (Marquant et al. 2016). Others have suggested that the true situation may be more complicated (Poole et al. 2006). Nevertheless, SES is a potential confounder in studies of childhood leukemia, providing there are associations of SES with natural background radiation. Studies have suggested that this is the case, with stronger associations between radon levels and SES for radon (Kendall et al. 2016a) than for gamma-rays (G Kendall et al. 2018). Most of the registry-based studies take SES into account (Mazzei-Abba et al. 2020). However, as discussed by Galobardes et al (Galobardes et al. 2006a, b) there is no single indicator of SES suitable for all study aims and applicable at all time points in all settings. It is possible that a single measure may not capture the aspect that is important in a particular context. Where possible, investigators should make use of more than one SES measure.

Associations have been reported between childhood leukemia and

- Birthweight (O'Neill et al. 2015)(Caughey and Michels 2009)

- Inadequate dietary folate (Cantarella et al. 2017)

- Daycare attendance (Kamper-Jørgensen et al. 2008)(Gilham et al. 2005)

- Allergies (Dahl et al. 2009)

- Breast Feeding (Martin et al. 2005)

It is plausible that some of these factors may vary with SES. As noted above, indoor radon concentrations tend to be lower in the homes of more deprived people, while gamma-ray levels are higher; the former trend is stronger. If a study reports opposite trends between 
childhood cancer and radon on the one hand and gamma-rays on the other (with the former being stronger) it may be a sign that residual confounding by SES is driving the findings.

The possibility of an unknown but powerful confounding factor is, of course, impossible to disprove and must always be a logical possibility. However, there is no obvious candidate environmental agent for most childhood cancers that would operate at a population level (Amirian et al. 2018; Cerhan et al. 2018; Hjalgrim et al. 2018; Linet et al. 2018). The great statistician, Ronald Fisher, suggested that confounding by an unspecified agent might account for the observed association between smoking and lung cancer (Fisher 1959). However, Richard Doll argued that confounding "needs to be explored but should not be postulated without some idea of what it might be" (Doll 2002).

\section{Doses from Radon and Decay Products}

Dosimetric calculations conclude that under normal exposure conditions, and for most organs outside the respiratory tract, doses from radon and decay products are lower than those from gamma and cosmic rays (Simmonds et al. 1995) (Kendall and Smith 2005). Doses from the penetrating gamma and cosmic rays do not vary very greatly across the body and may be taken as reasonably well established. But doses from radon decay products are very much harder to estimate. Most of the dose comes from alpha particles which have a range of at most a few cells. These alpha particles are emitted by radionuclides with half-lives of only a few tens of minutes and which may not have reached the organs or tissues where longer-lived isotopes of the same elements would undergo most of their decays. Moreover, there is often some uncertainty as to the nature and location of the sensitive target cells. There is thus inevitable uncertainty in the separation between the radionuclide emitting the short-range alpha particle and the sensitive target cells.

Under these circumstances, uncertainties in dosimetric calculations are substantial and it is hard to be absolutely certain that radon and its decay products might not play a greater part than might first be expected. That said, there is an element of conservatism in estimates of dose from radon decay products (Kendall and Smith 2005). However, no matter what the 
uncertainties in converting exposures to radon gas to doses to sensitive cells, the latter are highly likely to be broadly proportional to the mean radon concentration. So, analyses in terms of radon concentration should be a reliable guide to whether a hazard exists or not.

\section{Conclusions}

Do the studies discussed in this paper provide useful evidence on low dose radiation risks? In a sense, there is no doubt that they do, in that if radiation were a much more potent cause of childhood cancer than generally believed, this corpus of evidence would surely have demonstrated it. But interest inevitably centers on whether these studies, taken together, demonstrate a link between natural background radiation and childhood cancer or whether they are inconclusive. The complexity of the findings for many of the studies, and the different units in which they are expressed, preclude the inclusion in Table 1 of a simple judgement on each individual study. Moreover, excessive weight should not be given to whether individual studies achieve statistical significance or not - it is the combined weight of evidence from many studies on which judgements should be based. We now make some general points and refer to previous reviews before considering the register-based studies in more detail. Leukemia is the best studied of the childhood cancers and we give it most attention.

As noted in the introduction, ecological studies have intrinsic shortcomings which make them less reliable than individual-based studies. Further, it should be noted that ecological studies are at their most vulnerable when there is a strong confounding factor that may be driving findings. This situation does not apply to studies of childhood cancer, but we would generally give more weight to individual-based studies.

Raaschou-Nielsen (Raaschou-Nielsen 2008) reviewing studies of radon and childhood leukemia noted that ecological studies showed a consistent pattern of higher incidence and mortality rates for childhood leukemia in areas with higher average indoor radon concentrations. Case-control studies were more mixed, but overall were consistent with a weak association. There must be some concerns that these results might be influenced by reporting 
bias in which the positive studies, particularly the relatively simple ecological studies, might be more likely to overcome the various hurdles to be published and cited.

Lu et al (Lu et al. 2020) conducted a meta-analysis of 10 studies of exposure to radon and childhood leukemia published between 1995 and 2014. For the eight case-control studies there was a positive but weak association: Odds Ratio $1.22,95 \%$ CI 1.01-1.42. This was not the case for the two cohort studies: Hazard Ratio 0.97, 95\% CI 0.81-1.15. Lu et al reported that the overall ORs were not changed by removing any single study, suggesting the stability and reliability of these conclusions.

Leaving on one side the ecological investigations, Table 1 lists only three interview-based case-control studies of childhood leukemia and gamma rays (Axelson et al. 2002; Stjernfeldt et al. 1987; UK Childhood Cancer Study Investigators 2002a). The study of Stjernfeld has been described above and involved only 15 cases. That of Axelson was larger, with 312 cases. However, much the most weight should be given to the UKCCS, which included 2165 cases. Nevertheless, even this number left the study underpowered and, as the investigators acknowledged, unable to give useful information on the risks of exposure to indoor gamma rays. Participation bias was also a problem for the UKCCS.

The National Council on Radiation Protection and Measurements has recently published a review of the implications of epidemiologic studies for the linear-non-threshold model and radiation protection (NCRP 2018). This covered very much more than just studies of childhood cancer and natural background radiation. The potential problems that NCRP identified for studies of childhood leukemia generally were:

the limited applicability of the ambient radiation measurements, potential for uncontrolled confounding, participation rates, migration, and limited statistical power due to dose uncertainties and low doses. 
Problems with low and biased participation rates do not apply to register-based studies. Confounding and migration have been discussed above. Better statistical power is always to be desired, and bigger and/or pooled studies are to be encouraged; however, power for some of the larger national childhood cancer cohorts is between $50-90 \%$ (Kendall et al. 2013b) (Demoury et al. 2017), which is reasonable. The matter of limited applicability of ambient dose measurements is discussed in more detail by Till et al (Till et al. 2017), particularly in the context of epidemiological studies in areas with high natural background radiation. The dosimetry in a number of the natural background radiation studies was also reviewed by Daniels et al (Daniels et al. 2020). Daniels et al (Daniels et al. 2020) implicitly noted the importance of estimated indoor gamma radiation levels. In the context of exposure in early childhood it is exposure in the home environment that is likely to be critical, and as above it is highly desirable that dose to the relevant organ (e.g. bone marrow for leukaemia) be estimated, along with some measure of uncertainty. Personal dosimetry would indeed be preferable to measurements of ambient radiation levels though we suggest that the two are likely to be strongly correlated. Personal dosimetry on a sample basis has been suggested for register-based studies (MazzeiAbba et al. 2020). Little attention has been given to possible measurement errors in dose in background radiation studies. Fearn et al (Fearn et al. 2008) applied two methods, regression calibration and Monte Carlo maximum likelihood to assess the effects of errors in measurement of domestic radon exposure on lung cancer risk in a pooled analysis of lung cancer in Europe. Kendall et al (Kendall et al. 2013a) provided a detailed assessment of errors in dose in the British study, and suggested that these would probably have little effect.

It seems clear that most weight should be given to the nationwide register-based studies reviewed by Mazzei-Abba et al (Mazzei-Abba et al. 2020) to which should be added the recently published study by Berlivet et al (Berlivet et al. 2020). Table 2 compares the findings of these studies for leukemia and CNS tumors, the two most common types of childhood cancer. It should be noted that while most of these studies are of case-control design, that from Germany 
is ecological. In Table 2 and Figure 1 we regard results in terms of Odds Ratios and Relative Risks as effectively equivalent.

Significant positive associations were reported between gamma ray exposures and childhood leukemias in the British and Swiss studies, the latter being of borderline significance (Kendall et al. 2013b) (Spycher et al. 2015). Significant positive associations between gamma exposures and CNS tumors were reported from Switzerland and Germany (Spycher et al. 2015) (Spix et al. 2017) (the former again borderline). No studies found significant inverse associations. Figure 1 compares the relative risks with confidence intervals for the induction of childhood leukemia by gamma-rays for the five studies that investigated this question. Most confidence intervals overlap. There is a modest tendency for relative risks to be above one rather than below it. One striking factor is the dramatically tight confidence interval, centered on unity, for the French Study (Demoury et al. 2017). The reasons for this are not altogether clear. Other large studies with comparable numbers of cases and a similar underlying population dose distribution found much greater uncertainties (e.g. Kendall et al (Kendall et al. 2013b)).

The French study of Demoury et al. (Demoury et al. 2017) used dose estimates calculated by Warnery et al. (Warnery et al. 2015) which were based on a set of 98,858 indoor gammaray dose measurements at 17,420 dental surgeries and veterinary clinics. Billon et al., (Billon et al. 2005) had previously studied the gamma ray exposure of the French population, based on 8,737 measurements in private dwellings. The two studies found very different gamma ray mean dose rates: Billon et al. $55 \mathrm{nSv} / \mathrm{h}$; Warnery et al. $76 \mathrm{nSv} / \mathrm{h}$ (both net of the cosmic ray component). Marquant et al (Marquant et al. 2018) argued that the results of Warnery et al, which were more recent and covered all 96 départements of mainland France, rather than just 59 of them, are to be preferred. Nevertheless, the reason for the difference is not apparent (GM Kendall et al. 2018). However, it must be noted that Marquant et al reported that before Warnery's method became available, the French nation-wide ecological and case-control study data were analyzed using exposure metrics based on Billon's geolocated indoor and corrected 
outdoor large sets of measurements. No association of natural background radiation with childhood leukemia was observed, although the estimated power was, a priori, very good.

For induction of childhood leukemia by indoor radon the data in Table 2 are more equivocal than for gamma-rays. The Danish study is positive, albeit not quite achieving statistical significance, but the other three studies give little indication of an association.

There is no doubt that the national register-based studies provide more useful information on the associations between indoor gamma-ray exposures and the risk of childhood leukemia than did their predecessors. For radon the newer studies are equivocal and provide little support for the weak association suggested by previous studies (Raaschou-Nielsen 2008).

Perhaps the safest conclusion at this stage is that firm conclusions cannot yet be reliably drawn about natural background radiation and childhood cancer. In his famous "Modern English Usage", Fowler remarked that he could not tell whether a particular neologism would be extinguished by traditionalists or become a normal part of the language: "Our grandchildren will know". In the present case we may hope that clarity will come rather more quickly. There are reasons to be optimistic. New studies are in preparation and a Finnish study (Nikkilä et al. 2020) has been published, albeit too late to be included in this review. Work is well advanced on an update of the Swiss study (Spycher et al. 2015) and work continues on Phase II of the British study which will be twice as large as Phase I (Kendall et al. 2013b). The EU-funded RadoNorm project includes a task on radon and the risks of pediatric leukemia and brain tumors. There is very probably other work under way. In addition to these new studies, the pooling of separate datasets is likely to be very informative (Mazzei-Abba et al. 2020). This will provide more statistical power than the individual studies, and a more stable estimate of effect. It should be noted that the updated British study will likely be dominant in studies of natural background radiation in Europe, and would therefore have considerable influence in any pooled analysis. Nevertheless, bringing the different study designs onto a common footing is a substantial challenge, particularly as regards the various dosimetric methods employed (Milder et al. 2021). 


\section{Acknowledgements}

We are grateful to numerous colleagues for helpful discussions, most particularly to the authors of the earlier reviews that we cite. The two anonymous referees made helpful suggestions. The Intramural Research Program of the National Institutes of Health, the National Cancer Institute, Division of Cancer Epidemiology and Genetics supported the work of MPL.

\section{Disclosure Statement}

Richard Wakeford receives a consultancy fee as a member of the Technical Working Party of the Compensation Scheme for Radiation-linked Diseases (http://www.csrld.org.uk). Dr Kendall and Dr Little report no conflict of interest 


\section{References}

Alexander FE, McKinney PA, Cartwright RA. 1990. Radon and leukaemia. Lancet 335:1336-1337.

Amirian ES, Ostrom QT, Liu Y, Barnholtz-Sloan J, Bondy ML. 2018. Nervous system. In: Cancer epidemiology and prevention fourth edition, (Thun MJ, Linet MS, Cerhan JR, Haiman CA, Schottenfeld D, eds). New York, NY:Oxford University Press, 1039-1060.

Andersen CE, Raaschou-Nielsen O, Andersen HP, Lind M, Gravesen P, Thomsen BL, et al. 2007. Prediction of $222 \mathrm{rn}$ in danish dwellings using geology and house construction information from central databases. Radiation Protection Dosimetry 123: 83-94.

Appleton JD, Miles JCH. 2010. A statistical evaluation of the geogenic controls on indoor radon concentrations and radon risk. J Environ Radioact 101:799-803.

Arnold L. 2001. Britain and the h-bomb. Basingstoke:Palgrave Macmillan.

Arvela H, Hyvönen H, Lemmelä H. 1995. Indoor and outdoor gamma radiation in finland. Radiation Protection Dosimetry 1995 59:25-32.

Axelson O, Fredrikson M, Åkerblom G, Hardell L. 2002. Leukemia in childhood and adolescence and exposure to ionizing radiation in homes built from uranium-containing alum shale concrete. Epidemiology (Cambridge, Mass) 13:146-150.

Berlivet J, Hémon D, Cléro É, Ielsch G, Laurier D, Guissou S, et al. 2020. Ecological association between residential natural background radiation exposure and the incidence rate of childhood central nervous system tumors in france, 2000-2012. J Environ Radioact 211:106071.

Billon S, Morin A, Caër S, Baysson H, Gambard JP, Backe JC, et al. 2005. French population exposure to radon, terrestrial gamma and cosmic rays. Radiation Protection Dosimetry 113:314-320.

Bräuner EV, Andersen CE, Andersen HP, Gravesen P, Lind M, Ulbak K, et al. 2010. Is there any interaction between domestic radon exposure and air pollution from traffic in relation to childhood leukemia risk? Cancer causes \& control : CCC 21:1961-1964.

Breiman L. 2001. Random forests. Mach Learn 45:5-32.

Butland BK, Muirhead CR, Draper GJ. 1990. Radon and leukaemia. Lancet 335:1338-1339.

Cantarella CD, Ragusa D, Giammanco M, Tosi S. 2017. Folate deficiency as predisposing factor for childhood leukaemia: A review of the literature. Genes \& Nutrition 12:14.

Caughey RW, Michels KB. 2009. Birth weight and childhood leukemia: A meta-analysis and review of the current evidence. International journal of cancer 124:2658-2670.

Cerhan JR, Vajdic CM, Spinelli JJ. 2018. The non-hodgkin lymphomas. In: Cancer epidemiology and prevention fourth edition, (Thun MJ, Linet MS, Cerhan JR, Haiman CA, Schottenfeld D, eds). New York, NY:Oxford University Press, 767-796.

Chen J, Xie L. 2019. Domestic radon exposure and childhood leukaemia and lymphoma: A population-based study in canada. Radiation Protection Dosimetry 184:486-492.

Chernyavskiy P, Kendall GM, Wakeford R, Little MP. 2016. Spatial prediction of naturally occurring gamma radiation in great britain. Journal of Environmental Radioactivity 164:300-311.

Cohen BL. 1995. Test of the linear-no threshold theory of radiation carcinogenesis for inhaled radon decay products. Health Physics 68:157-174

Cohen BL. 2000. Testing a beir-vi suggestion for explaining the lung cancer vs. Radon relationship for u.S. Counties. Health Phys 78:522-527.

Commoner B. 1958. The fallout problem. Science 127:1023.

Cornfield J, Haenszel W, Hammond EC, Lilienfeld AM, Shimkin MB, Wynder EL. 1959. Smoking and lung cancer: Recent evidence and a discussion of some questions. JNCI: Journal of the National Cancer Institute 22:173-203.

Court Brown WM, Spiers FW, Doll R, Duffy BJ, McHugh MJ. 1960. Geographical variation in leukaemia mortality in relation to background radiation and other factors. Br Med J 1:1753-1759.

Dahl S, Schmidt LS, Vestergaard T, Schüz J, Schmiegelow K. 2009. Allergy and the risk of childhood leukemia: A meta-analysis. Leukemia 23:2300-2304.

Daniels RD, Kendall GM, Thierry-Chef I, Linet MS, Cullings HM. 2020. Strengths and weaknesses of dosimetry used in studies of low-dose radiation exposure and cancer. J Natl Cancer Inst Monogr 2020:114-132. Darby S, Hill D, Auvinen A, Barros-Dios JM, Baysson H, Bochicchio F, et al. 2005. Radon in homes and risk of lung cancer: Collaborative analysis of individual data from 13 european case-control studies. BMJ 330:223-227. Del Risco Kollerud R, Blaasaas KG, Claussen B. 2014. Risk of leukaemia or cancer in the central nervous system among children living in an area with high indoor radon concentrations: Results from a cohort study in norway. Br J Cancer 111:1413-1420.

Demoury C, Marquant F, Ielsch G, Goujon S, Debayle C, Faure L, et al. 2017. Residential exposure to natural background radiation and risk of childhood acute leukemia in france, 1990-2009. Environmental Health Perspectives 125:714-720.

Doll R. 2002. Proof of causality: Deduction from epidemiological observation. Perspect Biol Med 45:499-515. Evrard A-S, Hémon D, Billon S, Laurier D, Jougla E, Tirmarche M, et al. 2006. Childhood leukemia incidence and exposure to indoor radon, terrestrial and cosmic gamma radiation. Health Phys 90:569-579. 
Evrard AS, Hémon D, Billon S, Laurier D, Jougla E, Tirmarche M, et al. 2005. Ecological association between indoor radon concentration and childhood leukaemia incidence in france, 1990-1998. Eur J Cancer Prev 14:147157.

Fearn T, Hill DC, Darby SC. 2008. Measurement error in the explanatory variable of a binary regression:

Regression calibration and integrated conditional likelihood in studies of residential radon and lung cancer. Stat Med 27:2159-2176.

Fisher RA. 1959. Smoking: The cancer controversy. Edinburgh and London:Oliver and Boyd.

Foreman NK, Thorne R, Berry PJ, Oakhill A, Mott MG. 1994. Childhood malignancies in the south-west region of england, 1976-1985. Med Pediatr Oncol 23:14-19.

Friedman JH. 2001. Greedy function approximation: A gradient boosting machine. The Annals of Statistics 29:1189-1232.

Friedman JH. 2002. Stochastic gradient boosting. Computational Statistics \&amp; Data Analysis 38:367-378.

Galobardes B, Shaw M, Lawlor DA, Lynch JW. 2006a. Indicators of socioeconomic position (part 1). Journal of Epidemiology and Community Health 60:7-12.

Galobardes B, Shaw M, Lawlor DA, Lynch JW. 2006b. Indicators of socioeconomic position (part 2). Journal of Epidemiology and Community Health 60:95-101.

Gilbert ES, Little MP, Preston DL, Stram DO. 2020. Issues in interpreting epidemiologic studies of populations exposed to low-dose, high-energy photon radiation. J Natl Cancer Inst Monogr 2020:176-187.

Gilham C, Peto J, Simpson J, Roman E, Eden TOB, Greaves MF, et al. 2005. Day care in infancy and risk of childhood acute lymphoblastic leukaemia: Findings from uk case-control study. BMJ: British Medical Journal 330:1294-1297.

Gilman EA, Knox EG. 1998. Geographical distribution of birth places of children with cancer in the uk. Br J Cancer 77:842-849.

Greaves M. 2018. A causal mechanism for childhood acute lymphoblastic leukaemia. Nature Reviews Cancer $18: 471-484$.

Greaves MF. 1988. Speculations on the cause of childhood acute lymphoblastic leukemia. Leukemia 2:120-125. Greenland S, Robins J. 1994. Invited commentary: Ecologic studies--biases, misconceptions, and counterexamples. Am J Epidemiol 139:747-760.

Hauri D, Spycher B, Huss A, Zimmermann F, Grotzer M, von der Weid N, et al. 2013. Domestic radon exposure and risk of childhood cancer: A prospective census-based cohort study. Environ Health Perspect 121:1239-1244. Henshaw DL, Eatough JP, Richardson RB. 1990. Radon as a causative factor in induction of myeloid leukaemia and other cancers. Lancet 335:1008-1012.

Hjalgrim H, Chang ET, Glaser SL. 2018. Hodgkin lymphoma. In: Cancer epidemiology and prevention fourth edition, (Thun MJ, Linet MS, Cerhan JR, Haiman CA, Schottenfeld D, eds). New York, NY:Oxford University Press, 745-765.

Hunter N, Muirhead CR, Miles JC, Appleton JD. 2009. Uncertainties in radon related to house-specific factors and proximity to geological boundaries in england. Radiat Prot Dosimetry 136:17-22.

International Commission on Radiological Protection. 1993. Protection against radon-222 at home and at work. (Annals of the ICRP).ICRP.

Jacobson AP, Plato PA, Frigerio NA. 1976. The role of natural radiations in human leukemogenesis. Am J Public Health 66:31-37.

Kaletsch U, Kaatsch P, Meinert R, Schüz J, Czarwinski R, Michaelis J. 1999. Childhood cancer and residential radon exposure - results of a population-based case-control study in lower saxony (germany). Radiation and environmental biophysics 38:211-215.

Kamper-Jørgensen M, Woodward A, Wohlfahrt J, Benn CS, Simonsen J, Hjalgrim H, et al. 2008. Childcare in the first 2 years of life reduces the risk of childhood acute lymphoblastic leukemia. Leukemia 22:189-193.

Kendall G, Chernyavskiy P, Appleton J, Miles J, Wakeford R, Athanson M, et al. 2018. Modelling the bimodal distribution of indoor gamma-ray dose-rates in great britain. Radiat Environ Biophys 57:321-347.

Kendall GM, Smith TJ. 2005. Doses from radon and its decay products to children. J Radiol Prot 25:241-256. Kendall GM, Bunch KJ, Miles JCHM, Vincent TJ, Little MP, Wakeford R, et al. 2013a. Report of a recordbased case-control study of natural background radiation and incidence of childhood cancer in great britain. Chilton,Didcot:Health Protection Agency.

Kendall GM, Little MP, Wakeford R, Bunch KJ, Miles JCH, Vincent TJ, et al. 2013b. A record-based casecontrol study of natural background radiation and the incidence of childhood leukaemia and other cancers in great britain during 1980-2006. Leukemia 27:3-9.

Kendall GM, Wakeford R, Bunch KJ, Vincent TJ, Little MP. 2015. Residential mobility and associated factors in relation to the assessment of exposure to naturally occurring radiation in studies of childhood cancer. $\mathrm{J}$ Radiol Prot 35:835-868.

Kendall GM, Miles JCH, Rees D, Wakeford R, Bunch KJ, Vincent TJ, et al. 2016a. Variation with socioeconomic status of indoor radon levels in great britain: The less affluent have less radon. Journal of Environmental Radioactivity 164:84-90.

Kendall GM, Wakeford R, Athanson M, Vincent TJ, Carter EJ, McColl NP, et al. 2016b. Levels of naturally occurring gamma radiation measured in british homes and their prediction in particular residences. Radiation and Environmental Biophysics 55:103-124. 
Kendall GM, Little MP, Wakeford R. 2018. Comment on "indoor terrestrial gamma dose rate mapping in france: A case study using two different geostatistical models" by warnery et al. (j. Environ. Radioact. 2015, 139, 140148). Journal of Environmental Radioactivity 182:172-173.

Kinlen L. 1988. Evidence for an infective cause of childhood leukaemia: Comparison of a scottish new town with nuclear reprocessing sites in britain. The Lancet 332:1323-1327.

Kneale GW, Stewart AM. 1987. Childhood cancers in the uk and their relation to background radiation. In: Radiation and health: The biological effects of low-level exposure to ionizing radiation, (Russell Jones R, Southwood R, eds). Chichester:John Wiley \& Sons, 203-220.

Knox EG, Stewart AM, Gilman EA, Kneale GW. 1988. Background radiation and childhood cancers. J Radiol Prot 8:9-18.

Kohli S, Brage HN, Löfman O. 2000. Childhood leukaemia in areas with different radon levels: A spatial and temporal analysis using gis. J Epidemiol Community Health 54:822-826.

Krewski D, Lubin JH, Zielinski JM, Alavanja M, Catalan VS, Field RW, et al. 2006. A combined analysis of north american case-control studies of residential radon and lung cancer. J Toxicol Environ Health A 69:533597.

Kroll ME, Stiller CA, Murphy MFG, Carpenter LM. 2011. Childhood leukaemia and socioeconomic status in england and wales 1976-2005: Evidence of higher incidence in relatively affluent communities persists over time. Br J Cancer 105:1783-1787.

Land CE. 1980. Estimating cancer risks from low doses of ionizing radiation. Science 209:1197-1203.

Laurier D, Valenty M, Tirmarche M. 2001. Radon exposure and the risk of leukemia: A review of epidemiological studies. Health physics 81:272-288.

Linet MS, Morton LM, Devesa SS, Dores GM. 2018. Leukemias. In: Cancer epidemiology and prevention fourth edition, (Thun MJ, Linet MS, Cerhan JR, Haiman CA, Schottenfeld D, eds). New York, NY:Oxford University Press, 715-744.

Little MP, Wakeford R, Lubin JH, Kendall GM. 2010. The statistical power of epidemiological studies analyzing the relationship between exposure to ionizing radiation and cancer, with special reference to childhood leukemia and natural background radiation. Radiat Res 174:387-402.

Long L, Li F, Zhao Y, Sun H. 2010. Leukemia in children caused by indoor radon exposure: A case- control study China Modern Doctor 48:50-51.

Lu Y, Liu L, Chen O, Wei J, Cao G, Zhang J. 2020. Domestic radon exposure and risk of childhood leukemia: A meta-analysis. Official journal of the Balkan Union of Oncology 25:1035-1041.

Lubin J, Hauptmann M, Blair A. 2018. Indirect adjustment of relative risks of an exposure with multiple categories for an unmeasured confounder. Annals of Epidemiology 28:801-807.

Lubin JH, Linet MS, Boice JD, Buckley J, Conrath, S.M, Hatch EE, et al. 1998. Case-control study of childhood acute lymphoblastic leukemia and residential radon exposure. J Natl Cancer Inst 90:294-300.

Lubin JH. 2002. The potential for bias in cohen's ecological analysis of lung cancer and residential radon. J Radiol Prot 22:141-148.

Lubin JH, Wang ZY, Boice JD, Xu ZY, Blot WJ, De Wang L, et al. 2004. Risk of lung cancer and residential radon in china: Pooled results of two studies. International journal of cancer 109:132-137.

Lucie NP. 1990. Radon and acute lymphoblastic leukaemia. Leukemia and lymphoma 3:213-216.

Maged AF, Mokhtar GM, El-Tobgui MM, Gabbr AA, Attia NI, Abu Shady MM. 2000. Domestic radon concentration and childhood cancer study in cairo, egypt. Environ carcino \& ecotox revs C18:153-170. Marquant F, Goujon S, Faure L, Guissou S, Orsi L, Hémon D, et al. 2016. Risk of childhood cancer and socioeconomic disparities: Results of the french nationwide study geocap 2002-2010. Paediatr Perinat Epidemiol 30:612-622.

Marquant F, Demoury C, Ielsch G, Laurier D, Hémon D, Clavel J. 2018. Response to comment on "indoor terrestrial gamma dose rate mapping in france: A case study using two different geostatistical models" by warnery et al. Journal of Environmental Radioactivity 182:174-176.

Martin RM, Gunnell D, Owen CG, Smith GD. 2005. Breast-feeding and childhood cancer: A systematic review with metaanalysis. International journal of cancer 117:1020-1031.

Mason TJ, Miller RW. 1974. Cosmic radiation at high altitudes and u.S. Cancer mortality, 1950-1969. Radiat Res 60:302-306.

Mazzei-Abba A, Folly CL, Coste A, Wakeford R, Little MP, Raaschou-Nielsen O, et al. 2020. Epidemiological studies of natural sources of radiation and childhood cancer: Current challenges and future perspectives. J Radiol Prot 40:R1-R23.

McCulloch WS, Pitts W. 1943. A logical calculus of the ideas immanent in nervous activity. The bulletin of mathematical biophysics 5:115-133.

Milder CM, Kendall GM, Arsham A, Schöllnberger H, Wakeford R, Cullings HM, et al. 2021. Summary of radiation research society online 66th annual meeting, symposium on "epidemiology: Updates on epidemiological low dose studies", including discussion. International journal of radiation biology. Muirhead CR, Kneale GW. 1989. Prenatal irradiation and childhood cancer. J Radiol Prot 9:209-212. Muirhead CR, Butland BK, Green BMR, Draper GJ. 1991. Childhood leukaemia and natural radiation. Lancet 337:503-504.

Muirhead CR, Butland BK, Green BMR, Draper GJ. 1992. An analysis of childhood leukaemia and natural radiation in britain. Radiat Prot Dosimetry 45:657-660. 
NCRP. 2018. Implications of recent epidemiologic studies for the linear nonthreshold model and radiation protection, commentary no. 27 Bethesda, MD:National Council on Radiation Protection and Measurements. Nikkilä A, Erme S, Arvela H, Holmgren O, Raitanen J, Lohi O, et al. 2016. Background radiation and childhood leukemia: A nationwide register-based case-control study. International journal of cancer 139:1975-1982. Nikkilä A, Kendall G, Raitanen J, Spycher B, Lohi O, Auvinen A. 2018. Effects of incomplete residential histories on studies of environmental exposure with application to childhood leukaemia and background radiation. Environmental research 166:466-472.

Nikkilä A, Arvela H, Mehtonen J, Raitanen J, Heinäniemi M, Lohi O, et al. 2020. Predicting residential radon concentrations in finland: Model development, validation, and application to childhood leukemia. Scandinavian journal of work, environment \& health 46:278-292.

O'Neill KA, Murphy MF, Bunch KJ, Puumala SE, Carozza SE, Chow EJ, et al. 2015. Infant birthweight and risk of childhood cancer: International population-based case control studies of 40000 cases. Int J Epidemiol 44:153168.

Piantadosi S, Byar DP, Green SB. 1988. The ecological fallacy. Am J Epidemiol 127:893-904.

Pincet J, Massé L. 1975. Natural radiation and cancer mortality in several areas of north brittany. Int J Epidemiol 4:311-316.

Poole C, Greenland S, Luetters C, Kelsey JL, Mezei G. 2006. Socioeconomic status and childhood leukaemia: A review. Int J Epidemiol 35:370-384.

Puskin JS. 2003. Smoking as a confounder in ecologic correlations of cancer mortality rates with average county radon levels. Health Physics 84:526-532.

Raaschou-Nielsen O. 2008. Indoor radon and childhood leukaemia. Radiat Prot Dosimetry 132:175-181. Raaschou-Nielsen O, Andersen CE, Andersen HP, Gravesen P, Lind M, Schüz J, et al. 2008. Domestic radon and childhood cancer in denmark. Epidemiology 19:536-543.

Richardson S, Monfort C, Green M, Draper GJ, Muirhead C. 1995. Spatial variation of natural radiation and childhood leukaemia incidence in great britain. Stat Med 14:2487-2501.

Rybach L, Bachler D, Bucher B, Schwartz GF. 2002. Radiation doses of swiss population from external sources. J Envirin Radioact 62:277-286.

Sakka M. 1979. Background radiation and childhood cancer mortality. Nippon Acta Radiologica 39:536-539. Schubauer-Berigan MK, Berrington de Gonzalez A, Cardis E, Laurier D, Lubin JH, Hauptmann M, et al. 2020. Evaluation of confounding and selection bias in epidemiological studies of populations exposed to low-dose, high-energy photon radiation. JNCI Monographs 2020:133-153.

Simmonds JR, Robinson CA, Phipps A, Muirhead CRI, Fry FA. 1995. Nrpb r276: Risks of leukaemia and other cancers in seascale from all sources of ionising radiation exposure. London:HMSO.

Simon S. 1997. A brief history of people and events related to atomic weapons testing in the marshall islands. Health physics 73:5-20.

Simon S, Bouville A, Land C, Beck H. 2010. Radiation doses and cancer risks in the marshall islands associated with exposure to radioactive fallout from bikini and enewetak nuclear weapons tests: Summary. Health physics 99:105-123.

Sinnaeve J, Clemente G, O'Riordan MC. 1984. The emergence of natural radiation. Radiation Protection Dosimetry 7:15-17.

Spix C, Grosche B, Bleher M, Kaatsch P, Scholz-Kreisel P, Blettner M. 2017. Background gamma radiation and childhood cancer in germany: An ecological study. Radiat Environ Biophys 56:127-138.

Spycher BD, Lupatsch JE, Zwahlen M, Röösli M, Niggli F, Grotzer MA, et al. 2015. Background ionizing radiation and the risk of childhood cancer: A census-based nationwide cohort study. Environmental Health Perspectives 123 622-628.

Steinbuch M, Weinberg CR, Buckley JD, Robison LL, Sandler DP. 1999. Indoor residential radon exposure and risk of childhood acute myeloid leukaemia. Br J Cancer 81:900-906.

Stewart A, Webb J, Giles D, Hewitt D. 1956. Malignant disease in childhood and diagnostic irradiation in utero. Lancet 268:447-448.

Stidley CA, Samet JM. 1993. A review of ecologic studies of lung cancer and indoor radon. Health Phys 65:234251.

Stjernfeldt M, Samuelsson L, Ludvigsson J. 1987. Radiation in dwellings and cancer in children. Pediatr Hematol Oncol 4:55-61.

Thorne R, Foreman NK, Mott MG. 1996. Radon in devon and cornwall and paediatric malignancies. European journal of cancer (Oxford, England : 1990) 32A:282-285.

Till JE, Beck HL, Grogan HA, Caffrey EA. 2017. A review of dosimetry used in epidemiological studies considered to evaluate the linear no-threshold (lnt) dose-response model for radiation protection. International journal of radiation biology 93:1128-1144.

Tong J, Qin L, Cao Y, Li J, Zhang J, Nie J, et al. 2012. Environmental radon exposure and childhood leukemia. J Toxicol Environ Health B Crit Rev 15:332-347.

UK Childhood Cancer Study Investigators. 2002a. The united kingdom childhood cancer study of exposure to domestic sources of ionising radiation: 2: Gamma radiation. Br J Cancer 86:1727-1731.

UK Childhood Cancer Study Investigators. 2002b. The united kingdom childhood cancer study of exposure to domestic sources of ionising radiation: 1: Radon gas. Br J Cancer 86:1721-1726. 
UNSCEAR. 1958. Report to the general assembly with scientific annexes. Vienna:United Nations Scientific Committee on the Effects of Atomic radiation.

UNSCEAR. 1977. Sources, effects and risks of ionizing radiation. Report to the general assembly with annex b: Natural sources of radiation. . New York:United nations.

UNSCEAR. 1988. Report of the united nations scientific committee on the effects of atomic radiation official records. New York:United Nations.

UNSCEAR. 2000. United nations scientific committee on the effects of atomic radiation sources and effects of ionising radiation. 2000 report to the general assembly with scientific annexes. New York:United Nations.

Wakefield M, Kohler JA. 1991. Indoor radon and childhood cancer Lancet 338:1537-1538

Warnery E, Ielsch G, Lajaunie C, Cale E, Wackernagel H, Debayle C, et al. 2015. Indoor terrestrial gamma dose rate mapping in france: A case study using two different geostatistical models. J Environ Radioact 139:140-148. Yoshinaga S, Tokonami S, Akiba S, Nitta H, Kabuto M, Japan Childhood Cancer Study Group. 2005. Casecontrol study of residential radon and childhood leukemia in japan: Results from preliminary analyses.

International Congress Series 1276:233-235. 
Table 1 Epidemiological Studies of Childhood Cancer and Natural Background Radiation

\begin{tabular}{|c|c|c|c|c|c|c|c|}
\hline Author & Year & $\begin{array}{l}\text { Country } \\
\text { (Region) }\end{array}$ & Diseases & $\begin{array}{l}\text { Study } \\
\text { Design }\end{array}$ & Agent & $\begin{array}{l}\text { Cases/contr } \\
\text { ols }\end{array}$ & Reference \\
\hline Sakka & 1979 & $\begin{array}{l}\text { Japan } \\
\text { (Mijagi Prefecture) }\end{array}$ & All childhood cancers & Ecological & Gamma & 92 & (Sakka 1979) \\
\hline Stjernfeld & 1987 & $\begin{array}{l}\text { Sweden } \\
\text { (Östergötland) }\end{array}$ & Leukemia & Case/Control & Radon \& Gamma & $15 / 15$ & (Stjernfeldt et al. 1987) \\
\hline Knox et al & 1988 & Great Britain & All cancers & Ecological & Gamma & 22351 & (Knox et al. 1988) \\
\hline Alexander & 1990 & England and Wales & Leukemia & Ecological & Radon & 438 & (Alexander et al. 1990) \\
\hline Butland & 1990 & $\begin{array}{l}\text { International } \\
(7 \text { countries })\end{array}$ & Leukemia & Ecological & Radon & unclear & (Butland et al. 1990) \\
\hline Henshaw & 1990 & $\begin{array}{l}\text { International } \\
\text { (15 countries })\end{array}$ & Leukemia & Ecological & Radon & unclear & (Henshaw et al. 1990) \\
\hline Lucie & 1990 & $\begin{array}{l}\text { Great Britain } \\
(23 \text { counties })\end{array}$ & Leukemia & Ecological & Radon & unclear & (Lucie 1990) \\
\hline Muirhead & 1991 & Great Britain & Leukemia & Ecological & Radon \& Gamma & 6691 & (Muirhead et al. 1991) \\
\hline Wakefield & 1991 & $\begin{array}{l}\text { Great Britain } \\
\text { (Wessex) }\end{array}$ & Leukemia & Case/Control & Radon & $42 / 39$ & (Wakefield and Kohler 1991) \\
\hline Muirhead & 1992 & Great Britain & Leukemia & Ecological & Radon \& Gamma & 6691 & (Muirhead et al. 1992) \\
\hline Foreman & 1994 & $\begin{array}{l}\text { England } \\
\text { (5 SW counties) }\end{array}$ & Leukemia & Ecological & Radon & 678 & (Foreman et al. 1994) \\
\hline Richardson & 1995 & Great Britain & Leukemia & Ecological & Radon \& Gamma & 6691 & (Richardson et al. 1995) \\
\hline Thorne & 1996 & $\begin{array}{l}\text { England (Devon } \\
\text { \& Cornwall) }\end{array}$ & All childhood cancers & Ecological & Radon & 301 & (Thorne et al. 1996) \\
\hline Gilman & 1998 & Great Britain & Leukemia & Ecological & Radon \& Gamma & 9363 & (Gilman and Knox 1998) \\
\hline Lubin & 1998 & $\begin{array}{l}\text { USA } \\
\text { (9 states) }\end{array}$ & Leukemia & Case/Control & Radon & $505 / 443$ & (Lubin et al. 1998) \\
\hline Kaletsch & 1999 & $\begin{array}{l}\text { Germany } \\
\text { (Niedersachsen) }\end{array}$ & Leukemia & Case/Control & Radon & $164 / 209$ & (Kaletsch et al. 1999) \\
\hline Steinbuch & 1999 & USA & Leukemia & Case/Control & Radon & $173 / 254$ & (Steinbuch et al. 1999) \\
\hline Kohli & 2000 & $\begin{array}{l}\text { Sweden } \\
\text { (Östergötland) }\end{array}$ & Leukemia & Ecological & Radon & 90 & (Kohli et al. 2000) \\
\hline Maged & 2000 & Egypt (Cairo) & Leukemia & Case/Control & Radon & $50 / 110$ & (Maged et al. 2000) \\
\hline Axelson & 2002 & Sweden & Leukemia & Case/Control & Gamma & $312 / 1418$ & (Axelson et al. 2002) \\
\hline
\end{tabular}




\begin{tabular}{|c|c|c|c|c|c|c|c|}
\hline UKCCS & 2002 & Great Britain & All childhood cancers & Case/Control & Radon & $2226 / 3773$ & $\begin{array}{l}\text { (UK Childhood Cancer Study } \\
\text { Investigators 2002b) }\end{array}$ \\
\hline $\mathrm{UKCCS}$ & 2002 & Great Britain & All childhood cancers & Case/Control & Gamma & $2165 / 5086$ & $\begin{array}{l}\text { (UK Childhood Cancer Study } \\
\text { Investigators 2002a) }\end{array}$ \\
\hline Evrard & 2005 & France & Leukemia & Ecological & Radon & 4015 & (Evrard et al. 2005) \\
\hline Yoshinaga & 2005 & Japan & Leukemia & Case/Control & Radon & $255 / 248$ & (Yoshinaga et al. 2005) \\
\hline Evrard & 2006 & France & Leukemia & Ecological & Radon \& Gamma & 5330 & $\begin{array}{l}\text { (Evrard et al. 2006)Health Phys. 90: } \\
569-79 \text {. }\end{array}$ \\
\hline $\begin{array}{l}\text { Raaschou- } \\
\text { Nielsen }\end{array}$ & 2008 & Denmark & $\begin{array}{l}\text { Leukemia, lymphoma, } \\
\text { CNS }\end{array}$ & Case/Control & Radon & $2400 / 6697$ & (Raaschou-Nielsen et al. 2008) \\
\hline Brauner & 2010 & Denmark & Leukemia & Case/Control & Radon & $985 / 1969$ & (Bräuner et al. 2010) \\
\hline Long & 2010 & China (Hunan) & Leukemia & Case/Control & Radon & $56 / 112$ & (Long et al. 2010) \\
\hline Hauri & 2013 & Switzerland & All childhood cancer & $\begin{array}{l}\text { Census- } \\
\text { based } \\
\text { Cohort }\end{array}$ & Radon & 997 & (Hauri et al. 2013) \\
\hline Kendall & 2013 & Great Britain & All childhood cancer & Case/Control & Radon \& Gamma & $27447 / 36793$ & (Kendall et al. 2013b) \\
\hline $\begin{array}{l}\text { Del Risco } \\
\text { Kollerud }\end{array}$ & 2014 & $\begin{array}{l}\text { Norway } \\
\text { (Oslo region) }\end{array}$ & Leukemia, CNS & Cohort & Radon & 864 & (Del Risco Kollerud et al. 2014) \\
\hline Spycher & 2015 & Switzerland & All childhood cancer & $\begin{array}{l}\text { Census- } \\
\text { based } \\
\text { Cohort }\end{array}$ & Gamma & 1782 & (Spycher et al. 2015) \\
\hline Nikkilä & 2016 & Finland & Leukemia & Case/Control & Gamma & $1093 / 3279$ & (Nikkilä et al. 2016) \\
\hline Demoury & 2017 & France & Leukemia & Ecological & Radon \& Gamma & 9056 & (Demoury et al. 2017) \\
\hline Demoury & 2017 & France & Leukemia & Case/Control & Radon \& Gamma & $2763 / 30000$ & (Demoury et al. 2017) \\
\hline Spix & 2017 & Germany & Leukemia, CNS & Ecological & Gamma & 22652 & (Spix et al. 2017) \\
\hline Chen \& Xie & 2019 & $\begin{array}{l}\text { Canada } \\
(23 \text { census areas })\end{array}$ & Leukemia, lymphoma & Ecological & Radon & unclear & (Chen and Xie 2019) \\
\hline Berlivet & 2020 & France & $\mathrm{CNS}$ & Ecological & Radon \& Gamma & 5471 & (Berlivet et al. 2020) \\
\hline
\end{tabular}

* Where no region is shown the study covered the whole of the country 
Table 2 Nationwide Register-based Studies of Natural Background Radiation and childhood leukemia and CNS Tumors

\begin{tabular}{|c|c|c|c|c|c|c|c|}
\hline & & \multicolumn{3}{|c|}{ Leukemias } & \multicolumn{3}{|c|}{ CNS Tumors } \\
\hline & Study & Cases & RR - Radon & $R R$ - Gamma & Cases & $R R$ - Radon & $R R$ - Gamma \\
\hline Denmark & $\begin{array}{l}\text { Raaschou- } \\
\text { Nielsen } 2008 \\
\end{array}$ & 1,153 & $1.34(0.97-1.85)^{\mathrm{a}}$ & & 922 & $\begin{array}{c}1.34(0.97-1.85) \\
\mathrm{a}\end{array}$ & \\
\hline $\begin{array}{l}\text { Great } \\
\text { Britain }\end{array}$ & Kendall 2013 & 9,058 & $1.03(0.96-1.11)$ & $1.12(1.03-1.22)$ & 6585 & $1.15(0.88-1.50)$ & $1.02\left(\begin{array}{c}0.96-1.09) \\
\mathrm{c}\end{array}\right.$ \\
\hline Switzerland & Haurii 2013 & 283 & $0.90(0.68-1.19)^{b}$ & & 258 & $\begin{array}{c}0.92(0.69-1.22) \\
\mathrm{b}\end{array}$ & \\
\hline Switzerland & Spycher 2015 & 1782 & & $1.04 \begin{array}{c}(1.00-1.08) \\
\mathrm{c}\end{array}$ & 530 & & $\begin{array}{c}1.04(1.00-1.08) \\
\mathrm{c}\end{array}$ \\
\hline Finland & Nikkilä 2016 & 1,093 & & $0.97(0.89-1.06)$ & & & \\
\hline France & Demoury 2017 & 2,763 & $1.00(0.97-1.02)$ & $1.00(0.99-1.01)$ & & & \\
\hline France & Berlivet 2020 & & & & 5471 & $\begin{array}{c}1.02(0.96-1.07) \\
b\end{array}$ & $1.03(0.98-1.09)$ \\
\hline Germany & Spix 2017 & 13,374 & & $1.04 \underset{\mathrm{d}}{(0.91-1.20)}$ & 9048 & & $\begin{array}{c}1.35(1.17-1.57) \\
\mathrm{d}\end{array}$ \\
\hline
\end{tabular}

Data are Relative Risk (or Odds Ratio) per mSv cumulative equivalent dose to the red bone marrow unless otherwise stated a per $10^{3} \mathrm{~Bq} \mathrm{~m}^{-3}$ years

b per $10^{3} \mathrm{~Bq} \mathrm{~m}^{-3}$

c per $\mathrm{mSv}$ cumulative effective dose (whole body)

d Comparing 1.5 vs $0.5 \mathrm{mSv} / \mathrm{a}$ for acute lymphoid leukemia

e per $50 \mathrm{nSv} / \mathrm{h}$

After Mazzei-Abba et al (Mazzei-Abba et al. 2020) 
Caption to Figure 1: Relative Risks (Odds Ratios) with 95\% confidence interval for induction of childhood leukemia by natural background gamma-rays in nationwide register-based studies from different countries. 


\section{Appendix: Methods of dose estimation in register-based studies of childhood cancer and natural background radiation}

\section{Radon}

Evrard et al (Evrard et al. 2005) estimated indoor radon concentrations in the 348 zones d'emploi (ZE) of France. Exposure assessment was based on a campaign of 13,240 measurements covering the whole country. Measurements were made in selected dwellings using passive track-etch detectors, normally with a single measurement in each dwelling, but with a second measurement to confirm unusually low or high values.

Evrard et al (Evrard et al. 2006) estimated indoor radon concentrations for the 95 Département of France using similar methods to those of Evrard et al 2005.

Raaschou-Nielsen et al (Raaschou-Nielsen et al. 2008) estimated indoor radon concentrations in dwellings from a set of 3116 1-year indoor measurements using regression analysis (Andersen et al. 2007). Geographical region, soil type, and a number of house characteristics (such as type of house, floor, basement, and building materials) were used as predictive factors.

Kendall et al (Kendall et al. 2013a) used two sources of radon concentration estimates in homes:

1. Mean exposures in County Districts, from the National Survey; the radon analogues of the gamma-ray estimates (see below).

2. A predictive radon map developed by the Health Protection Agency and British Geological Survey (HPA/BGS), which was based on the results of about 400000 measurements of radon concentrations in homes grouped by grid squares and boundaries between different geological units. The uncertainties in these predictions have been considered by Hunter et al 2009 (Hunter et al. 2009) and by Appleton and Miles 2010 (Appleton and Miles 2010).

Hauri et al (Hauri et al. 2013) estimated indoor radon concentrations in homes using a nationwide radon prediction model. This model was based on almost 45,000 measurements from the Swiss National radon database. A multivariable log-linear regression model was 
fitted. The most relevant predictors for indoor radon levels were tectonic units (i.e., geological features such as moraines) and year of construction of the building, followed by soil texture, degree of urbanization, floor of the building where the measurement was taken and housing type.

Demoury et al (Demoury et al. 2017) estimated radon exposures (at the town center for the incidence study and at the residence address for the case-control study) using a co-kriging model. This made use of

1. A set of radon concentration measurements made with passive track-etch detectors in 10,843 dwellings.

2. A map of geogenic radon potential. This initially classified areas by uranium content and then refined the estimates by taking into account additional parameters which control the pathways of radon through the ground and may increase the radon potential.

Dose estimates by Berlivet et al (Berlivet et al. 2020) appear to be the same as the dose estimates used by Demoury et al (Demoury et al. 2017).

\section{Gamma-rays (with or without cosmic and artificial components)}

Evrard et al (Evrard et al. 2006) estimated indoor gamma-ray dose rates for the 95 Départements in France using a set of 8,737 measurements from the French National Survey and also measurements from TLDs used to monitor the level of environmental radioactivity at about 1,000 sites. The cosmic ray components were subtracted using the UNSCEAR 2000 formula.

Kendall et al (Kendall et al. 2013a) estimated gamma-ray dose rates (including the directly ionising component of cosmic rays) at the birth location of study subjects as the mean for the English County District or comparable administrative areas in Wales and Scotland. There are 459 such units in Great Britain. Means were calculated using measurements in 2283 randomly selected dwellings in Great Britain as part of the UK survey of naturally occurring indoor radiation levels. 
Spycher et al (Spycher et al. 2015) used estimates of outdoor gamma ray dose rates for 2 $\mathrm{km} \times 2 \mathrm{~km}$ grid cells. These had been estimated by Rybach et al (Rybach et al. 2002) by combining the contributions from

1. The directly ionizing component of cosmic rays, estimated by formula,

2. Terrestrial gamma rays, estimated by airborne gamma-ray spectrometry, in situ gamma-ray spectrometry and rock/soil sample data,

3. Anthropogenic radiation (almost entirely Cs-137 from Chernobyl), estimated by in situ and airborne spectrometric measurements.

Grid cell dose rates for the terrestrial components were interpolated from the available data points using the inverse distance method and a search radius of $12 \mathrm{~km}$.

Nikkilä et al (Nikkilä et al. 2016) estimated indoor gamma ray dose rates using a map of outdoor dose rates by $8 \times 8 \mathrm{~km}$ squares prepared by STUK, the Finnish Radiation and Nuclear Safety Authority, on the basis of a nationwide mobile survey (Arvela et al. 1995). Conversion to indoor dose rates was done using indoor dose rate measurements in 346 dwellings coupled with information on house characteristics from national datasets. Cosmic ray doses were estimated by formula and subtracted from the measurements. An estimate of doses from Chernobyl fallout was included.

Spix et al (Spix et al. 2017) analysed in terms of ambient outdoor dose equivalent rate measured directly at the 1808 stations of the IMIS network. IMIS is the Integrated Measuring and Information System for the Surveillance of Environmental Radioactivity operated by the Bundesamt für Strahlenschutz, the Federal Office for Radiation Protection. This use of directly measured doses is, we think, unique in these studies. Indoor doses were not estimated.

Demoury et al (Demoury et al. 2017) estimated exposures to gamma-rays and cosmic rays as the average dose rate of $1 \times 1 \mathrm{~km}$ squares (over the municipality territory for the incidence study and at the residence address for the case-control study). Cosmic ray doses were estimated using the model of UNSCEAR (UNSCEAR 2000). The gamma-ray components were estimated using a multi-collocated cokriging model. This made use of 
1. A set of 97,595 measurements in 17,404 dentist surgeries and veterinary clinics using Radio Photo Luminescent dosimeters,

2. A map of geogenic radon potential (as used for radon estimation)

Dose estimates by Berlivet et al (Berlivet et al. 2020) seem the same as the dose estimates used by Demoury et al (Demoury et al. 2017).

\section{Further investigations of methods to estimate indoor gamma-ray dose rates}

Kendall et al have explored a number of possible methods for improved estimates of indoor gamma ray dose rates to be used in an updated study of natural background radiation and childhood cancer in Great Britain. The 2013 publication (Kendall et al. 2013a) had used mean values for 459 County districts, the means being based on 2283 indoor measurements.

The first paper (Kendall et al. 2016b) used an expanded set of 10,199 indoor gamma-ray dose rate measurements. Outdoor gamma-ray dose-rates were tabulated for each $10 \mathrm{~km}$ square of the National Grid. As explanatory variables two types of geological coding were used: LEXROCK Bedrock and 50K-BEDSUP which combined simplified bedrock and superficial components. The latter had been developed by the British Geological Survey for use in radon mapping. For geostatistical modelling a simplified set of 16 bedrock classes was developed.

A number of ad-hoc and geostatistical models were employed. The former included means over geological or administrative areas and distance weighted mean of nearest measurements to the point of interest. In addition, the paper examined an optimal linear combination of a selection of these results (the "E-OLS" model).

A Gaussian-Matérn ("GM") geostatistical model was also employed in which an underlying spatial variation was modified by a Gaussian stochastic process with Matérn correlation structure that models the observed tendency of dose rates in neighboring houses to correlate more than would be indicated by geology alone.

In the second paper (Chernyavskiy et al. 2016) additional geological data included a simplified set of 23 surface geological classes, broadly analogous to the bedrock classes, and 
also a combined bedrock and surface classification (23-levels) that were still further reduced. Both Multi-Resolution Gaussian Process (MRGP) models and four variogram based parametric spatial models were tested.

In the third paper (G Kendall et al. 2018) a new set of explanatory variables were available. These were census variables (socio-economic status; population density; urban/rural status) and a classification into Pre/Post 1940 construction. The models tested were a variety of Gaussian-Matérn geostatistical model together with models tested in previous papers.

In work presently in hand, an expanded set of explanatory variables, including new descriptive data on the housing stock in small areas, is being tested using machine learning models, specifically random forests (Breiman 2001), stochastic gradient boosting machines (Friedman 2001) (Friedman 2002) and neural networks (McCulloch and Pitts 1943). The random forest models use a slight adaptation of the standard Breiman-Cutler algorithm, altering the stopping criterion used to limit tree expansion. The housing data so far explored comprises area means of the following variables:
(a) year of construction,
(b) value of property,
(c) number of bedrooms,

also the percentage of properties of each housing type (bungalow, maisonette, terraced, semidetached, detached etc) within the area. 